\title{
Interaction of drought and frost in tree ecophysiology: rethinking the timing of risks
}

\author{
Guillaume Charrier ${ }^{1}$ (D) Nicolas Martin-StPaul ${ }^{2} \cdot$ Claire Damesin $^{3} \cdot$ Nicolas Delpierre $^{3} \cdot$ Heikki Hänninen $^{4}$. \\ Jose M. Torres-Ruiz ${ }^{1} \cdot$ Hendrik Davi $^{2}$
}

Received: 8 December 2020 / Accepted: 26 February 2021 / Published online: 12 April 2021

(c) The Author(s) 2021, corrected publication 2021

\begin{abstract}
- Key message The increase in climate variability is likely to generate an increased occurrence of both frost-induced and drought-induced damages on perennial plants. We examined how these stress factors can potentially interact and would subsequently affect the vulnerability to each other. Furthermore, we discussed how this vulnerability could be modulated by shifts in the annual phenological cycle.

Context The edges of plant distribution are strongly affected by abiotic constraints: heat waves and drought at low latitude and elevation, cold and frost at high latitude and elevation. The increase in climate variability will enhance the probability of extreme events and thus the potential interaction of stress factors. The initial exposure to a first constraint may affect the vulnerability to a subsequent one.

Aims Although three integrative physiological processes, namely water balance, carbon metabolism and the timing of phenological stages, have largely been studied in the response of trees to a single constraint, their interaction has rarely been investigated. How would the interaction of frost and drought constraints modulate the vulnerability to a subsequent constraint and how vulnerability to a given constraint and phenology interact?

Conclusion We suggest that the interaction between frost and drought constraints should in the short-term influence water balance and, in the longer term, carbon metabolism, both consequently affecting further vulnerability. However, this vulnerability can be modulated by shifts in the annual phenological cycle. Significant gaps of knowledge are reported in a mechanistic framework. This framework can help to improve the current process-based models integrating the life history of the individual plant.
\end{abstract}

Keywords Abiotic stress $\cdot$ Acclimation $\cdot$ Carbon availability $\cdot$ Drought $\cdot$ Frost $\cdot$ Phenology $\cdot$ Risk assessment $\cdot$ Tree ecophysiology

\section{Introduction}

Handling Editor: Erwin Dreyer

Contribution of the co-authors GC, NMSP, and HD developed the ideas presented in this viewpoint piece and wrote the manuscript, with contributions from $\mathrm{CD}, \mathrm{ND}, \mathrm{HH}$, and JMTR.

This paper is part of the Topical Collection on Disturbances under climate change - Impacts of natural disturbances on forest ecosystems under climate change: large-scale analysis and modelling.

Guillaume Charrier

guillaume.charrier@inrae.fr

Extended author information available on the last page of the article
Abiotic (e.g., temperature, water, light, nutrients) and biotic factors (e.g., intra and interspecific competition, predation, parasitism) are the major drivers of plant distribution and evolutionary change (Erwin 2009; Klanderud et al. 2015). Although biotic factors drive population dynamics in the entire range, abiotic factors can be highly relevant at the rear and leading edges of the distribution (Hampe and Petit 2005). Within the boreal, alpine, temperate, and Mediterranean areas, plants are likely to be exposed to both drought and frost stress, although it may not happen every year. At the rear edge, drought stress is one of the critical abiotic factors (e.g., at low latitude and elevation in Europe; Loehle 1998; Lines et al. 2010; 
Ruiz-Benito et al. 2013). At the leading edge (high latitude and elevation), cold and freezing temperatures usually limit plant distribution (Gusta et al. 1983; Koerner 1998; Larcher 2005; Charrier et al. 2013a). Along a latitudinal gradient within the niche of a species, drought and frost constraints are often separated; i.e., episodes of mild or severe drought are observed on the rear edge mostly during the summer, and frost stress on the leading edge during the autumn (early frosts), winter, or spring (late frosts). This has led to define the autoecological approach to predict the distribution of plant species within frost-exposed areas (boreal, alpine, temperate, and Mediterranean areas), considering individual limitations, such as minimum temperature at the leading edge or water deficit at the rear edge (Guisan and Thuiller 2005; Cheaib et al. 2012). However, drought and frost can co-occur at high elevation when, late in the winter, air temperature increases while soil is still frozen, inducing the so-called winter drought (Tranquillini 1979; Mayr and Charra-Vaskou 2007; Charrier et al. 2017). Drought and frost may also take place successively at the same location, affecting plant health and resistance to following stress factor (Kreyling et al. 2012). An alternative approach is thus required for taking the different involved processes into account, and, more importantly, for addressing their interaction to improve the actual species distribution models.

This is even more crucial since dramatic changes in climate are likely to increase exposure to abiotic constraints over all biomes (IPCC 2012). Mean surface temperature increased at a rate of $0.2{ }^{\circ} \mathrm{C}$ per decade over the last decades, leading to species migration at higher latitudes and elevation (Parmesan and Yohe 2003; Lenoir et al. 2008). Ecosystem functioning is likely to be affected by these changes, however, through contradictory effects. On the one hand, increased productivity is expected in relation to longer growing season (early flushing dates and delayed senescence; Schaber and Badeck 2005; Menzel et al. 2006; Fu et al. 2014; Keenan and Richardson 2015). On the other hand, a substantial deterioration in various physiological processes is expected to be induced by an insufficient winter chilling that would alter plant development (Chuine et al. 2016; Delpierre et al. 2016), or increased climatic hazards such as drought (Porporato et al. 2004; Allen et al. 2010; Carnicer et al. 2012) or late frost events (Leinonen and Hänninen 2002; Augspurger 2013).

The extreme climatic events (e.g., drought, frost, heat spell, and storm) play a major role in the distribution, survival, and, therefore, adaptation of plants (Chapin et al.
1993; van Peer et al. 2004), as well as in the productivity and the composition of communities (Knapp et al. 2002). The expected increase in climate variability will inevitably lead to an increase in the frequency, intensity, and duration of extreme events (IPCC 2012; Rummukainen 2012; Seneviratne et al. 2012). If the return period of two extreme events is divided by two (e.g., a 100-year episode occurring twice more often), the return period of the interaction between these two constraints should happen four times more often. How these extreme events will affect ecosystem functions is a key issue for climatologists, ecologists, and modelers (IPCC 2014; Ummenhofer and Meehl 2017). In this regard, perennial plants, and especially trees, which are keystones structuring many ecosystems, sheltering biodiversity, and being an important carbon stock, are the most likely to be affected by an increased exposure to abiotic constraints, even though they may not reach the lethal threshold at once (Chuste et al. 2019). An accurate assessment of the emerging risks and their impacts on the physiology of trees is therefore urgently needed to predict dynamics of forest ecosystems and ultimately their influence on the water and carbon cycles at the global scale.

The risk of developing significant damages is only achieved at the crossing between climatic hazards (e.g., drought or frost constraint), stress exposure (e.g., low water potential or organ temperature), and tree vulnerability (e.g., low resistance to embolism or insufficient frost hardiness; Bréda and Peiffer 2014). The prediction of emerging risks therefore needs accurate assessments of (i) the exposure to a given abiotic constraint (type, intensity, duration, and frequency) and (ii) the spatio-temporal patterns of vulnerability and subsequent damages (e.g., perennial tissues facing early and winter frosts vs. flowers and flushing buds facing late frosts). The timing of critical phenological stages (e.g., bud burst date and leaf full expansion date with respect to frost and drought, respectively) would thus modulate risk and subsequent damages. How the exposure to a given abiotic constraint at a given time instant would influence the vulnerability to the same or a different constraint in the future is a critical issue that has been only rarely investigated (Miao et al. 2009; Anderegg et al. 2013; Batllori et al. 2017; Hossain et al. 2019).

The vulnerability to abiotic constraints (which is the susceptibility to develop damages facing a given stress intensity) has been studied for decades via three different focuses, namely phenology (Fig. 1 Frame C; Hänninen and Tanino 2011), water use (Fig. 1 Frame D, Choat et al. 2012; Anderegg et al. 2015), and carbon availability (Fig. 1 Frame 
B, Sala et al. 2012; Hartmann and Trumbore 2016). The individual responses of each tree ecophysiological process have been integrated into process-based models such as PHENOFIT (Morin and Chuine 2005), SUREAU (MartinStPaul et al. 2017), or CASTANEA (Dufrêne et al. 2005), for phenology, water use, and carbon availability, respectively. Facing constraints, the response of each process may not be linear. Therefore, the response to simultaneous or successive constraints may generate complex behavior. Integrating the physiological response to abiotic constraints is therefore needed to predict various forms of emergent behavior under new conditions imposed by climate change (Bartholomeus et al. 2011).

This paper summarizes the state-of-the-art of tree responses to drought and frost constraints and subsequent damages from the cellular to the individual scale with the aim of emphasizing the undervalued role of their interac- tions at the short-term scale (i.e., from day to year). In fact, so far, the different scientific communities have only focused in one of these processes at a time (e.g., hydraulic in response to drought, frost hardiness and damages, phenological cycles). The influence of previous stress factors on plant vulnerability is mainly relevant on perennial plants and will be mainly explored at the annual level through two main questions: (i) How would the interaction of drought and frost constraints modulate the vulnerability to a subsequent constraint? (ii) How do vulnerability to a given constraint and phenology interact? Addressing these questions will provide novel information about the interaction between climate and trees from a wider, multifactorial, and temporal perspective. This framework will be crucial to understand and predict local mortality dynamics and ultimately to improve current species distribution models.

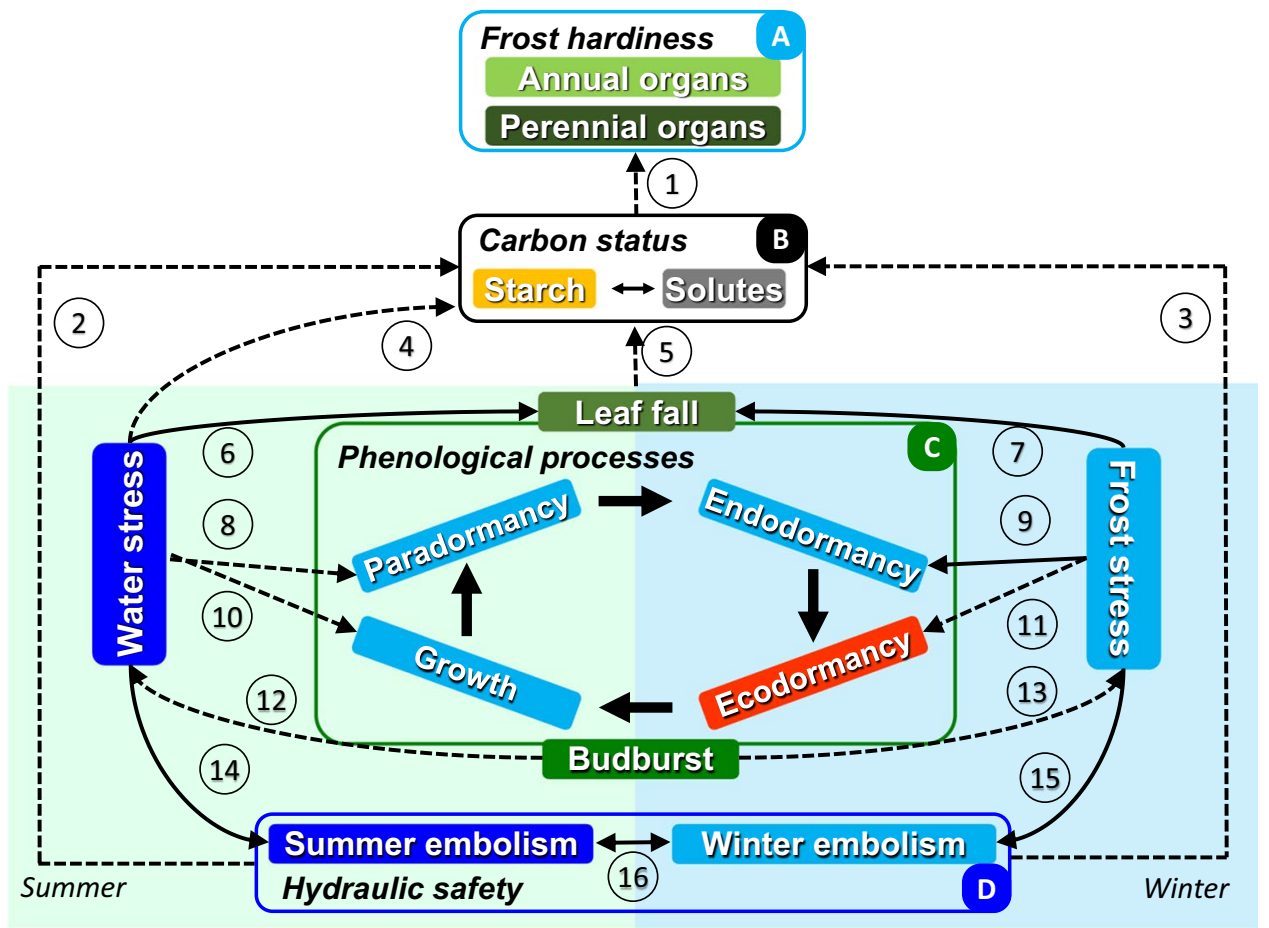

Fig. 1 Involved processes affected by water (mainly during the summer period) and frost stress (mainly during the winter period). Positive (solid) and negative (dashed) effects of stresses are expected on three functional components, namely carbon metabolism (B), phenological processes (C), and hydraulic safety (D). Positive relations between timing events (phenological stages such as leaf fall and budburst) and other processes indicate that earlier event induces higher level, and vice versa. All represented processes are interrelated either directly and indirectly. Both winter and summer stresses affect the same processes either synergistically or antagonistically. Main effects are reported, although non-linear and thresholds could make the response more complex. The numbers refer to studies that document these effects (1. Morin et al. 2007; 2. O’Brien et al. 2014; 3. Améglio et al. 2004; 4. McDowell etal. 2008; 5. Bréda et al. 2006; 6. Tyree et al. 1993; 7. Schuster et al. 2014; 8. Xie et al. 2015; 9. Rinne et al. 1997; 10. Chaves et al. 2002; 11. Charrier et al. 2011; 12. Ghesquière et al. 2014; 13. Hänninen 1991; 14. Sperry et al. 1998; 15. CharraVaskou et al. 2016; 16. Charrier et al. 2014) 


\section{How would the interaction of drought and frost constraints modulate the vulnerability to a subsequent constraint?}

Over the last decades, ecophysiological studies have led to a comprehensive understanding on the direct relation between abiotic constraints and physiological processes (Frames \#1 and \#2; Fig. 1). From a physical perspective, both drought and frost constraints are related to a limited liquid water availability. Similar damages are generated at both the cellular (i.e., plasmolysis and cell lysis; Levitt 1980; Siminovitch and Cloutier 1983) and vascular levels (i.e., cavitation and embolism when a critical level of water potential is reached; Sperry and Sullivan 1992; Charrier et al. 2014). A critical factor in the response to both stresses is the accumulation of solutes to maintain a solvation layer around macromolecules. Plants have thus developed similar molecular responses to drought and frost constraints (Beck et al. 2007), under the control of abscisic acid (ABA; Chandler and Robertson 1994), inducing, for instance, the synthesis of dehydrins (Welling et al. 2002). Interestingly, the molecular response to both constraints involves the same regulatory mechanisms (e.g., dehydration responsive elements containing cold binding factors; Stockinger et al. 1997; Baker et al. 1994). The same pathways are thus activated in both cold and drought responses (Yamaguchi-Shinozaki and Shinozaki 1994).

Frame 1 Mechanisms leading to drought-induced damages

Water stress results from an imbalance between inwards (root water absorption) and outwards water fluxes (transpiration and evaporation). Trees have developed resistance mechanisms to avoid water stress (maintaining high water potential; Fig. 1) by a tight control of both inwards (e.g., deep rooting) and outward water fluxes (e.g., stomatal closure, leaf shedding, low cuticular transpiration; Choat et al. 2018; Martin-StPaul et al. 2017). Maintaining xylem hydraulic function under high tension is also a critical trait to avoid dehydration, and ultimately desiccation, of living tissues (Fig. 1 \#14; Sperry et al. 1998, Brodribb and Cochard 2009). However, ontogenic changes in xylem vulnerability to embolism may modulate tree resistance across seasons (Charrier et al. 2018b). In some species, leaves are more drought-sensitive than perennial organs (i.e., hydraulic vulnerability segmentation) and usually fall after the exposure to drought (Fig. 1 \#6 Tyree et al. 1993). Such a deciduous behavior can be too sudden to allow recycling nutrients (Fig. 1 \#5 Bréda et al. 2006) but not in all cases (Marchin et al. 2010). Following leaf fall, the reestablishment of a new cohort of leaves would mobilize non-structural carbohydrate reserves, which may not be restored before the winter. Long-term drought induces stomatal closure to maintain the functionality of the hydraulic system. As respiration is maintained and even increased during warm spells, while carbon assimilation is reduced, carbon reserves steadily deplete (Fig. 2; McDowell et al. 2008). Finally, two pools, namely solutes, including carbohydrates, and water, interact to maintain a turgor and a solvation layer around biomolecules avoiding critical denaturation and related cellular death (Bowman and Roberts 1985; Martinez-Vilalta et al. 2019).

Frame 2 Mechanisms leading to frost-induced damages
Low temperature drives tree species distribution through different processes: including resistance to freezing temperature and to frost-induced embolism (Charrier et al. 2013a), the time to complete the annual cycle, and seedling survival (Koerner et al. 2016). In fully hydrated organs, ice formation can induce mechanical strains and frost cracks (Kubler 1983; Cinotti 1991). In moderately dehydrated organs, ice nucleation and propagation redistribute water towards nucleation sites (Ball et al. 2006; Mayr and Charra-Vaskou 2007) and likely provoke air seeding within pits (Charrier et al. 2014). However, frost-induced embolism in the distal parts would insulate the trunk from further dehydration (Fig. 1 \#15; Lemoine et al. 1999; Charrier et al. 2017). Critical thresholds can be reached when the root water absorption cannot compensate the evaporative demand during periods of sunny days alternating with freezing nights (i.e., winter drought; Tranquillini 1979; Charrier et al. 2017). At the cellular level, the low chemical potential of ice pulls water molecules from the cells towards extracellular ice lattice, causing pronounced cell dehydration and shrinkage (Dowgert and Steponkus 1984; Charra-Vaskou et al. 2016). To cope with seasonal frost stress, trees transiently increase their frost resistance in frost-exposed organs through the synthesis of cryoprotective solutes (Charrier et al. 2013b). Cryoprotective solutes (e.g., carbohydrates, amino acids, or organic acids) can protect macromolecules by maintaining a solvation layer around them. Being the main substrate and energetic source, non-structural carbohydrate content in the autumn is thus tightly related to maximum frost resistance reached during the winter (Fig. 1 \#1; Palonen and Buszard 1997; Morin et al. 2007; Charrier et al. 2013a; 2018c). As non-structural carbohydrate content usually increases with elevation through temperature-limited growth rather than by carbon availability (Hoch et al. 2002; Shi et al. 2008; Koerner 2015), the increase in NSC at higher elevation would help plants to reach sufficient level of frost resistance in the winter.

The onset of drought-induced damages is triggered by hydraulic failure and involves the interaction between water balance and carbon metabolism (Frame 1 and reviews from Choat et al. 2018; Martinez-Vilalta et al. 2019, for extensive description of drought stress syndromes), as for frost-induced damages (Charrier et al. 2013b; 2015). At the vascular level, species more vulnerable to winter embolism seem to be also more vulnerable to summer embolism (Charrier et al. 2014). This may be related to the ability of air to propagate within xylem under high frost-related or drought-related tension through bordered pits (Cochard et al. 1992). Despite current controversies on the ability of plant to restore its hydraulic conductivity under tension (e.g., Zwieniecki and Holbrook 2009; Brodersen et al. 2010; Lamarque et al. 2018), many tree species are able to restore their hydraulic conductivity under positive pressure, for instance to supply growth in the spring (Hacke and Sauter 1996; Cochard et al. 2001). In angiosperms, one refilling mechanism involves osmoregulation via solute compounds generating low osmotic potential in the lumen of the vessels during the winter (Ewers et al. 2001; Améglio et al. 2002), and eventually the summer (Nardini et al. 2011). A refilling mechanism has not yet been identified for conifers, but there is evidence that refilling likely occurs within several species 
(Sperry and Sullivan 1992; Sperry et al. 1994; Mayr et al. $2003 ; 2014)$. Positive sap pressure has also been measured at the whole plant scale from the pressurization of the root system, notably in woody lianas (Priestley 1920; Sperry et al. 1987; Charrier et al. 2016) and herbs (Gleason et al. 2017).

Embolism arising from the freezing of xylem sap and high tension arising from drought may interact. Such repeated freeze-thaw and drought events may lead to reduced embolism resistance (Mayr et al. 2003; 2007). This is because the initial exposure to freezing temperatures may result in the deformation of the ultrastructure of bordered pit membranes, which are critical for preventing the spread of gas from one conduit into another (Christensen-Dalsgaard and Tyree 2014). However, despite high xylem embolism has been suggested to cause plant death (Brodribb and Cochard 2009), higher embolism than 50\%, and even $90 \%$, is frequently observed and recovered in over-wintering trees without impairing their survival, which suggests that it does not constitute a lethal threshold by itself (Sperry et al. 1994; Mayr et al. 2003; 2006; 2019; Charrier et al. 2013a). High xylem embolism may be an empirical correlate with plant death, rather than a physiological cause (Mayr et al. 2019).

Although drought and frost stresses affect many physiological processes in the same way, it is not clear how the response to a repeated exposure could affect vulnerability to a given stress. As a first approximation, one would expect that a stress affecting the carbon balance may make the tree more vulnerable to subsequent stresses; e.g., defoliated oaks would decline within 2 years (Wargo 1981), or carbon-deprived spruces would die more rapidly from drought (Hartmann et al. 2013). This hypothesis fed into the socalled boxer theory, suggesting the successive stresses may cause trees to decline (Wargo 1996; Bréda and Peiffer 2014). Wood growth has been used as an integrative marker following frost and drought stress (Vanoni et al. 2016; d'Andrea et al. 2020). However, due to the difficulty of conducting long-term studies through the development of project-based funding, few studies have been able to accurately characterize the affected ecophysiological processes.

Two alternative processes, although not mutually exclusive, may help to predict the interaction between stress factors. Legacy is considered a passive change of physiological status in response to previous stress exposure. We suggest that the modulation of either carbon or water pools may result in the modulation of vulnerability (McDowell et al. 2008). Altered water balance and carbon metabolism would generate potential feedback physiological loops and trade-offs during successive abiotic stress exposures (legacy effect). Memory (also known as priming) relates to a defensive plant response to either biotic or abiotic stress (Savvides et al. 2016), and is considered an active process that shifts or enhances the basal resistance at the cost of reducing primary metabolism such as growth (Bruce et al. 2007; Walter et al. 2013; Martinez-Medina et al. 2016). Memory requires pre-exposure to the stress factor that will modulate the rate of plant response through the accumulation of regulatory proteins, transcription factors, or histone methylation. In contrast, acclimation occurs in response to a change in environmental conditions prior to stress exposure or after stress exposure. In long-living organisms such as trees, the concept of memory is uncommon because most of the studies dealing with memory have focused on short-term memory in annual plants. Some studies have evaluated how the vulnerability to a given constrain, i.e. frost or drought, is affected by a repeated exposure of trees to it (Mayr et al. 2003; Tomasella et al. 2019; Zweifel et al. 2020). However, studies evaluating the feedback between constraints and vulnerability (i.e., the effect of drought on vulnerability to frost and vice versa) are very few (e.g., Kreyling, et al. 2014; Feichtinger et al. 2015; Sierra-Almeida et al. 2016). We attempted to draw a generic picture as both constraints affect the same physiological processes (Fig. 1).

\section{Effect of drought on vulnerability to frost}

After a drought episode, an increase in solute concentration (i.e., lower osmotic potential) will decrease the freezing point $\left(-1.86{ }^{\circ} \mathrm{C} \mathrm{mol}^{-1} \mathrm{~kg}^{-1}\right.$; Hansen and Beck 1988) in both living cells (Charrier et al. 2013b) and the apoplasm (Lintunen et al. 2018). Soil water deficit can indeed initiate the early stages of frost hardiness in Douglas fir (Timmis and Tanaka 1976). This effect is likely to be canceled during the transition from drought-exposed to frost-exposed period in case of a wet autumn period, as often observed in temperate and montane area. However, changes in the water regime, as predicted by future climate predictions, could cause this dry summer and autumn conjunction to occur more regularly.

Lower frost vulnerability of trees pre-exposed to drought is thus expected through two potential side-effects: (i) lower probability of ice formation under similar sub-zero temperatures and (ii) higher probability of ice nucleation within the apoplasm, pulling symplasmic water towards extracellular ice lattice. However, this effect may be balanced by a decrease in non-structural carbohydrates due to photosynthesis limitation by stomatal closure, leading to similar or even lower solute concentration in drought-exposed trees. In fact, both effects have been observed in winter frost damages following summer drought. Increasing frost hardiness is thus expected for relatively moderate dehydration (Fig. 3 as observed in Benzioni et al. 1992; Kreyling et al. 2012; Sierra-Almeida et al. 2016). It should also be noted that growth-related processes are more sensitive to water stress than photosynthesis (Fig. 2a), and mild water stress is expected to promote transient increase in non-structural carbohydrates for moderate level of stress (McDowell 2011; 


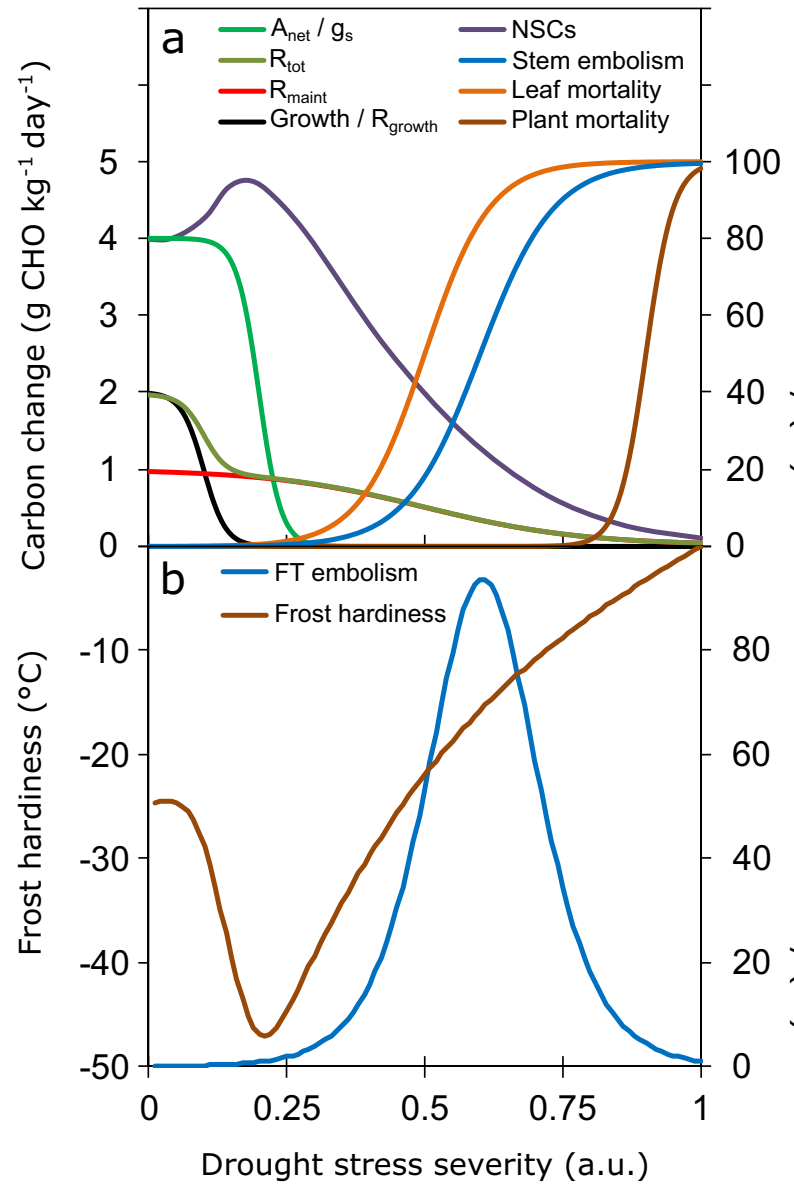

Fig. 2 A Processes and pools affected by drought stress intensity: photosynthesis $A_{\text {net }}$, stomatal conductance gs, respiration (growth $R_{\text {growth}}$, maintenance $R_{\text {maint }}$, and total $R_{\text {tot }}$ ), non-structural carbohydrates (NSCs), stem embolism, leaf and plant mortality. As growth is more sensitive to water stress than photosynthesis, and respiration, the NSC pool initially increases (McDowell 2011). After photosynthesis declines, NSCs decline, whereas leaf mortality, embolism, and plant mortality increase (Charrier et al. 2018b). B Potential effect generated by drought stress on frost hardiness of living cell (through the non-linear relation between NSC and water content) and vulnerability to freeze-thaw (FT)-induced embolism

Granda and Camarero 2017). However, would this transient increase result in higher reserves (potentially enhancing frost acclimation) or be allocated to other processes such as belowground growth? Finally, lower frost hardiness may be observed since higher drought stress level will result in lower carbon reserves and consequently reduced solutes (Fig. 3 right Wong et al. 2009; Galvez et al. 2013; Fig. 3).

From the xylem/hydraulic point of view, the resulting vulnerability to frost-induced embolism is only generated when sap is under moderate tension (Mayr et al. 2007). Freeze-thaw cycles will thus exacerbate the pre-existing tension promoting air seeding from vessel to vessel in dehydrated trees (Fig. 2b; Tyree and Sperry 1989; Mayr et al. 2007; Kasuga et al. 2015). Drought episodes during the

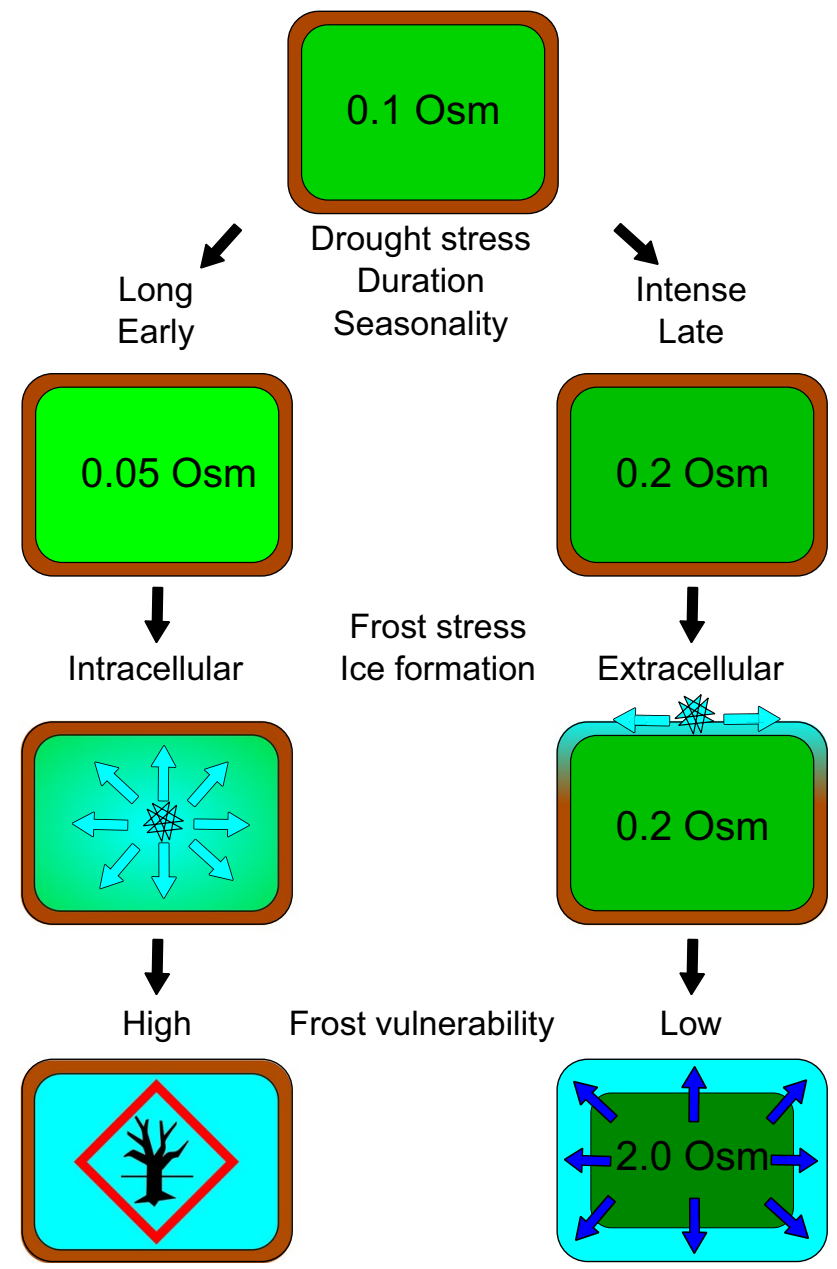

Fig. 3 Alternative pathways that would explain why contrasted frost vulnerabilities are observed after previous drought exposure. Osmolarity of intracellular sap, controlled notably by the ratio between soluble carbohydrates and water content, could be considered the main driver. On the right path, intense and/or late drought is expected to concentrate cell sap, increasing the probability of extracellular ice nucleation. The low chemical potential of ice would pull water, further increasing cell osmolarity. On the left path, long and/or early drought prevents timely increase in solutes, through reduction in carbon reserves. Intracellular freezing is expected to happen more often and at higher freezing temperature, inducing cellular damages

growing season may lead to the reduction in vessel diameter (Lovisolo and Schubert 1998; Beikircher and Mayr 2009) that would result in higher resistance to freeze-thaw-induced embolism. However, a reduced level of non-structural carbohydrates after severe drought stress will limit the ability of the tree to refill embolized vessels during the winter via active mechanisms (e.g., stem pressure; Améglio et al. 2001). The main positive effect (i.e., decreasing the vulnerability to frost-induced embolism) therefore may lie in the higher ability of sap to supercool and therefore avoid the phase shift from liquid to ice and the resulting formation of air bubbles (Lintunen et al. 2018). 


\section{Effect of frost on vulnerability to drought}

Major gaps of knowledge remain with respect to frost exposure onto drought vulnerability, although assumptions can be made. Overall, frost damages before drought exposure may mainly have negative effects for the trees through limited hydraulic conductivity and/ or biomass destruction, although the affected organs as well as the consequences for the tree can be various. However, we are not aware of a single study that specifically explored the physiological consequences of frost damages during the following growing season and after, although Charrier et al. (2018a) highlighted a significant negative correlation between autumnal frost damages and fruit yield the following summer in the walnut Juglans regia L.

Low, but not necessarily below $0{ }^{\circ} \mathrm{C}$, soil temperature limits root water uptake (Améglio et al. 2002). Thanks to thermal inertia, the combination of cold soil and warm and dry air can promote aboveground dehydration and hydraulic failure. This phenomenon, called winter drought, is typical of late winter conditions at high altitudes (Mayr et al. 2006; Charrier et al. 2017; Earles et al. 2018). Winter drought-induced and freeze/thaw-induced embolism increase the volume of gas within the xylem conduits, therefore facilitating the spreading of air through conduits (Lens et al. 2011). Furthermore, higher porosity of the pit membrane following freeze-thaw events has been observed for different species when evaluating defrosted wood samples (Li et al. 2016). Such changes in the pit membrane thickness are likely to increase drought vulnerability through air seeding (Charrier et al. 2014; Li et al. 2016). Such an increased vulnerability would only remain if the embolism is not refilled.

When the winter precipitation regimes change from solid to liquid, the shorter snow cover duration is likely to expose soil to lower temperature, damaging the root system more frequently (Francon et al. 2020). This would alter the whole tree hydraulic architecture by decreasing water supply and decreasing the ability to recover, ultimately increasing xylem embolism (Cox and Malcolm 1997; Zhu et al. 2000). This syndrome has been identified as pre-disposing dieback for the yellow birch Betula alleghaniensis (Cox and Zhu 2003).

Lower hydraulic conductivity from winter embolism and limited spring refilling will limit hydraulic conductance of the whole plant. Under relatively high evaporative demand (high VPD), it would result in lower leaf water potential and stomatal conductance. As partially open stomata allow sufficient $\mathrm{CO}_{2}$ diffusion while limiting the amount of transpired water, it is likely that water use efficiency would be increased. Soil water content would be depleted more slowly which would thus delay drought onset and intensity. The same dynamic is expected after late frost damages, as leaves would expand later in the season. However, at the stand scale, the competition for water resources from other tree individuals or other plant species (less vulnerable to winter embolism or frost damages) may eliminate this potential benefit (Bréda et al. 1995).

One important aspect to consider regarding frost damages is the temporality, since higher damages have been observed during the elongation period of new growth units in the spring (Chaar and Colin 1999). By destroying the developing organs, late frost damage (leaf, flowers, and new shoots) will immediately reduce the transpiration (water output) and the photosynthesis (carbon input). In addition, on a longer term, the remobilization of carbon reserves to reconstruct annual organs may result in a significant carbon depletion (Wargo 1996). Although under non-stressing circumstances carbon reserves are quickly restored, under drought stress, we could expect a significant limitation in the ability of the tree to maintain the stomata open and positive net carbon assimilation (O'Brien et al. 2014). Furthermore, assuming an increase in resistance to drought-induced embolism along the growing season, the newly formed xylem will be more vulnerable at the time when drought stress will be higher (Charrier et al. 2018b).

\section{Potential interaction between vulnerability to constraints and phenology}

The annual phenological cycle consists of developmental events related to the alternation of growth and dormancy of the trees. Longer growing seasons, such as predicted by vegetation models due to climate change, are expected to increase the carbon uptake and the ecosystem net primary production (Angert et al. 2005; Delpierre et al. 2009; Wolf et al. 2016). However, this could be at the cost of longer periods of effective transpiration that would, ultimately, deplete soil water content and thus increase the exposure to drought stress. Although timing is a crucial parameter in the exposure to a seasonal abiotic constraint, models predicting tree seasonality developed so far mostly consider non-stressing conditions (see Lang et al. 1987; Delpierre et al. 2016). Notably, do key variables of phenological simulations, such as critical sums of temperature for chilling and/or forcing stages, vary with stress intensity?

Photoperiod and temperature are key signals regulating plant phenology (Maurya and Bhalearao 2017). In the spring, ecodormancy release and growth (both primary and secondary) are accelerated by warm temperature, in some species in interaction with photoperiod (Laube 
et al. 2014). At the end of the growing season, growth cessation, bud set, and endodormancy are controlled by photoperiod and temperature through two distinct but temporally connected processes: one photosensitive (short day) and one thermosensitive (low temperature) (Tanino et al. 2010). Endodormancy is subsequently released by chilling temperature. Among these different stages, we can distinguish two different processes: temperature-promoted processes (i.e., occurring at a rate proportional to temperature such as ecodormancy release, primary and secondary growth, and budset) and signallimited processes (i.e., occurring after a specific threshold has been reached such as growth cessation, endodormancy induction, leaf fall), which are indirectly affected by photoperiod and temperature. However, the effect of abiotic stress on the different phenological processes and, furthermore, how carry-over effects can modulate pluriannual dynamics have not been fully characterized yet (Eilmann et al. 2011). Thus, depending on the timing of the previous stage, the onset of the following ones will be affected, leading to unpredictable behavior (Hänninen and Tanino 2011). For instance, an increase in temperature may hasten or delay growth cessation depending on the diurnal dynamics of temperature (see Rohde et al. 2011 and Kalcsits et al. 2009, respectively), affecting the subsequent stages (budset, endodormancy, and budburst; Fig. 4). Leaf senescence timing is positively correlated with budburst timing once removing the influence of (i) drought stress (Schuldt et al. 2020) and (ii) autumn

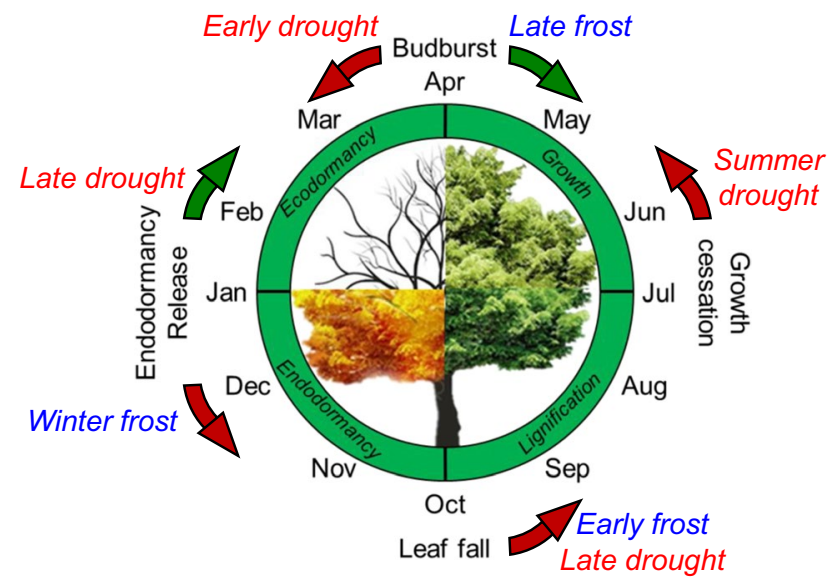

Fig. 4 Hastening (brown arrow) or delaying (green arrow) phenological stages in response to drought and frost events. At the center is presented the typical seasonal phenological stages in a deciduous tree in the Northern Hemisphere and outside the potential effects of drought and frost stress depending on their timing. It should be noted that stress factors can have a lagged effect onto phenology (e.g., late drought in the late summer delaying winter dormancy release). Early and late drought typically happen in May-June and September, respectively. Early and late frost typically happen in September-October and April-May, respectively temperature (Fu et al. 2014). The carry-over effect with respect to budburst is, however, of second order (Liu et al. 2019) and potentially hidden by the prominent role of environmental variables such as temperature and photoperiod (Vitasse et al. 2009). Such an interacting process has been incorporated in a leaf senescence model (Delpierre et al. 2009) by modulating the cold temperature sum leading to leaf senescence by the budburst date (Keenan and Richardson 2015).

Drought stress affects radial (i.e., secondary) growth but its effect on primary growth is relatively unexplored in trees. Drought exposure can significantly hasten the primary growth onset in Erica multiflora, although not in Globularia alypum (Bernal et al. 2011). However, also no effect on growth cessation has been reported (Bernal et al. 2011). One would expect that earlier growth onset would favor drought avoidance during springtime, but it could hasten soil water depletion and this may be at the cost of the alteration of the development of shoot, leaves, and buds (Misson et al. 2011). Autumnal drought is expected to induce earlier endodormancy, probably through the induction of ABA (Maurya and Bhalerao 2017; Tylewicz et al. 2018). Furthermore, higher temperatures associated with drought events may induce deeper dormancy (Heide 2003; Tanino et al. 2010; Rohde et al. 2011). As this may result in later budburst the following year, these trees are likely to be more drought-exposed since they would expand their leaves during a period of more pronounced water deficit. Delayed dormancy and budburst are thus expected through synergistic combination between drought exposure and carry-over effects (Xie et al. 2015).

The impact of frost events on phenology has essentially been reported in the spring when it affects developing organs such as flushing buds, flowers, and new leaves. After a single damaging event, the resulting leaf area (i.e., post growth) can be reduced (up to more than 50\%) and leaf full expansion delayed (16-34 days; Augspurger 2013). Delayed phenology will expose the tree to higher summer drought resulting in lower carbon reserves (Menzel et al. 2015; d'Andrea et al. 2019; 2020). During the late summer, after growth cessation and dormancy induction, frost exposure may promote the dormancy release andinduces leaf fall as cold temperature do (Rinne et al. 1997). So, depending on the timing, frost damages could delay or hasten the annual cycle (later leaf full expansion or earlier endodormancy release, after spring and autumn frost damage, respectively (Fig. 4)). In addition, frost events may induce both cellular and vascular damages in the distal organs, resulting in re-growth from more basal buds. After several years, the whole tree architecture may be affected resulting in smaller and denser canopy, which would be less frost exposed, but at the cost of canopy light transmittance and subsequent photosynthesis. 


\section{A holistic modeling framework for tree stress physiology: a tentative outline}

A living tree is a functionally holistic system including constantly interacting growth units. Accordingly, the various physiological processes are linked to each other. Two different physiological variables such as water potential and frost hardiness represent, at least partially, different manifestations of the same physiological phenomena (as described by the correlations between frost hardiness and water content (Charrier et al. 2013b) on one hand and water content and water potential on the other hand (Edwards and Jarvis 1982)).

Ecophysiological models have been developed separately for frost stress (Fuchigami et al. 1982; Leinonen 1996; Charrier et al. 2018a) and drought stress (Sperry et al. 1998; Zweifel et al. 2005; Martin-StPaul et al. 2017; Zweifel and Sterck 2018). By addressing the seasonal alternation of growth and dormancy, the annual phenological cycle also reflects major changes in the physiology of trees that could enhance or mitigate the vulnerability to stress factors. Accordingly, the integrated models of frost hardiness simulate the environmental responses of changes in frost hardiness according to the phenological stage (Kellomäki et al. 1992; 1995; Leinonen 1996; Charrier et al. 2018a). Seasonality is indeed located at the core of any modeling framework related to seasonal frost or drought stress factors. We first propose that existing ecophysiological models explicitly integrate seasonality weighing relevant parameters by the variables describing phenological processes (e.g., sum of growth degree days, sum of chilling units). Although not being mechanistic, these variables would unify the framework of the models, allowing further research into the deterministic relations between three highlighted processes (phenology, carbon dynamics, and plant hydraulics). Such an integrated modeling approach should be used for the interaction between stress factors through the following steps:

(i) Quantitative description of the variable(s) of interest e.g. loss of hydraulic conductivity and cellular lysis.

(ii) Identification of the relevant physiological drivers with special attention dedicated to the ones that interact with several variables of interest e.g. water or carbohydrate content.

(iii) Description of the relation between the drivers and the variable of interest e.g. relation between frost hardiness, tissue water content, carbohydrate, and temperature (Poirier et al. 2010).

(iv) Experimentally based description of the relation between physiological drivers and external climatic drivers to ensure realistic behavior. (v) Mathematical description of the relationship between physiological drivers and external climatic drivers e.g. carbohydrate content depending on air temperature (Charrier et al. 2018c).

(vi) Coupling the models obtained at steps (ii) and (iv) and development of a model predicting the variable of interest with input data being dynamic climate variables, state variables (such as specific parameters or initial values), and intermediate physiological drivers.

(vii) Simulate the tree response and compare with stressrelated variable such as frost hardiness vs. daily minimum temperature (Charrier et al. 2018a).

Finally, such approach will easily simulate both legacy and memory effects (as a function of previous level of damages, water, and carbon contents) and / variation in state variables for the different processes based on experimental data.

\section{Conclusion and perspectives}

Exposures to drought and frost constraints exert potential feedbacks on the sensitivity to future constraints by affecting physiological components such as non-structural carbohydrates and water balance (i.e., legacy Fig. 2). Phenological processes have been only studied in non-stressed plants, although physiological seasonality is altered by stress (Fig. 4). Major advances are needed in characterizing environmental control of phenological processes in trees during or after stress, potentially explaining the residual variance in current phenological predictions.

Phenological processes are likely to exhibit legacy through carbon balance e.g. trophic limitation of meristem growth (Bonhomme et al. 2010) and disturbed glycan deposition onto plasmodesmata (Rinne et al. 2001). However, previous exposure to stress factors may also alter the rate of the future ecophysiological response through memory effect via accumulation of regulatory proteins, transcription factors, or histone methylation (Bruce et al. 2007; Walter et al. 2013). As already performed in annual plants, there is a clear need for multi-constrained and longer-term studies in woody plants, such as promoted by the SOERE or the long-term ecological research network (Yonker et al. 2007).

To specifically deal with the interaction between constraints, we need to (i) develop a systemic approach at the plant scale integrating ontogenic and histological differences as well as carbon and water use coupled with the phenological dynamics; and (ii) develop a multi-collinearity approach aiming to evaluate the interactions between different constraints in the tree survival capacity both at short and 
long-time scale. Interesting insights have been brought by integrative studies, for instance, focusing on carbon availability and hydraulic failure facing drought (e.g., McDowell et al. 2008). It is especially relevant to develop this type of approaches on different species exhibiting contrasted combinations of drought and frost tolerance, including provenances originating from the entire species' distribution range (core and edges) to unravel local adaptations (Kreyling et al. 2014). The effect of different successive and concomitant constraints at different periods of the year should help to develop deterministic relationships between different physiological variables and processes in response to each of them. It would simulate the life history of the tree and modulate response through legacy and memory effects as a function of the previous level of damages, water, and carbon contents. Improving the descriptive range of these interrelations at the individual and population scales would subsequently allow quantitative and dynamic description of drought and frost resistance. This will improve existing mechanistic models simulating these interacting processes in order to predict accurately the effect of cumulative stress on tree physiology and survival.

Acknowledgements The authors would like to thank Rosana Lopez for the recommendation and Jordi Martinez-Vilalta and Sean Gleason for the reviews of a preliminary version of this manuscript (hal-02475505v4) through the Peer Community in Forest and Wood Sciences platform (https://doi.org/10.24072/pci.forestwoodsci.100001). The authors are also grateful to two anonymous reviewers for their constructive comments and Eric Dufrene for the insightful discussions related to the topic.

Funding This work has been carried out with financial support from the Pack Ambition Recherche program 'Doux-Glace' from the Auvergne-Rhône Alpes region. This work was also supported by the program ANR Acoufollow (ANR-20-CE91-0008) funded by the French National Agency for Research and the Austrian Science Fund. The article has been granted free Open Access under the agreement between INRAE and Springer Nature.

Data availability Data sharing not applicable to this article as no datasets were generated or analyzed during the current study.

\section{Declarations}

Conflict of interest The authors declare no competing interests.

Open Access This article is licensed under a Creative Commons Attribution 4.0 International License, which permits use, sharing, adaptation, distribution and reproduction in any medium or format, as long as you give appropriate credit to the original author(s) and the source, provide a link to the Creative Commons licence, and indicate if changes were made. The images or other third party material in this article are included in the article's Creative Commons licence, unless indicated otherwise in a credit line to the material. If material is not included in the article's Creative Commons licence and your intended use is not permitted by statutory regulation or exceeds the permitted use, you will need to obtain permission directly from the copyright holder. To view a copy of this licence,visit http://creativecommons.org/licenses/by/4.0/.

\section{References}

Allen CD, Macalady AK, Chenchouni H et al (2010) A global overview of drought and heat-induced tree mortality reveals emerging climate change risks for forests. For Ecol Manage 259:660-684

Améglio T, Ewers FW, Cochard H, Martignac M, Vandame M, Bodet C, Cruiziat $P$ (2001) Winter stem xylem pressure in walnut trees: effects of carbohydrates, cooling and freezing. Tree Physiol 21:387-394

Améglio T, Bodet C, Lacointe A, Cochard H (2002) Winter embolism, mechanisms of xylem hydraulic conductivity recovery and springtime growth patterns in walnut and peach trees. Tree Physiol 22:1211-1220

Améglio T, Decourteix M, Alves G et al (2004) Temperature effects on xylem sap osmolarity in walnut trees: evidence for a vitalistic model of winter embolism repair. Tree Physiol 24:785-793

Anderegg WR, Plavcová L, Anderegg LD, Hacke UG, Berry JA, Field CB (2013) Drought's legacy: multiyear hydraulic deterioration underlies widespread aspen forest die-off and portends increased future risk. Glob Change Biol 19:11881196

Anderegg WR, Flint A, Huang CY et al (2015) Tree mortality predicted from drought-induced vascular damage. Nat Geosci $8: 367-371$

Angert A, Biraud S, Bonfils C et al (2005) Drier summers cancel out the $\mathrm{CO} 2$ uptake enhancement induced by warmer springs. Proc Natl Acad Sci USA 102:10823-10827

Augspurger CK (2013) Reconstructing patterns of temperature, phenology, and frost damage over 124 years: spring damage risk is increasing. Ecology 94:41-50

Baker SS, Wilhelm KS, Thomashow MF (1994) The 50-region of Arabidopsis thaliana cor15a has cis-acting elements that confer cold, drought, and ABA-regulated gene expression. Plant Mol Biol 24:701-713

Ball MC, Canny MJ, Huang CX, Egerton JJG, Wolfe J (2006) Freeze/thaw-induced embolism depends on nadir temperature: the heterogeneous hydration hypothesis. Plant Cell Environ 29:729-745

Bartholomeus RP, Witte JPM., van Bodegom PM, van Dam JC, Aerts $R$ (2011) Climate change threatens endangered plant species by stronger and interacting water-related stresses. J Geophys Res Biogeosci 116. https://doi.org/10.1029/2011JG001693

Batllori E, De Cáceres M, Brotons L, Ackerly DD, Moritz MA, Lloret F (2017) Cumulative effects of fire and drought in Mediterranean ecosystems. Ecosphere 8:e01906

Beck EH, Fettig S, Knake C, Hartig K, Bhattarai T (2007) Specific and unspecific responses of plants to cold and drought stress. J Biosci 32:501-510

Beikircher B, Mayr S (2009) Intraspecific differences in drought tolerance and acclimation in hydraulics of Ligustrum vulgare and Viburnum lantana. Tree Physiol 29:765-775

Benzioni A, Palzkill DA, Nelson JM (1992) Flower bud dormancy, $\mathrm{ABA}$ concentration, and survival during frost of jojoba genotypes under water stress. J Am Soc Hortic Sci 117:976-980

Bernal M, Estiarte M, Peñuelas J (2011) Drought advances spring growth phenology of the Mediterranean shrub Erica multiflora. Plant Biol 13:252-257

Bonhomme M, Peuch M, Ameglio T, Rageau R, Guilliot A, Decourteix M, Alves G, Sakr S, Lacointe A (2010) Carbohydrate uptake from xylem vessels and its distribution among stem tissues and buds in walnut (Juglans regia L.). Tree Physiology 30:89-102

Bowman WD, Roberts SW (1985) Seasonal and diurnal water relations adjustments in three evergreen chaparral shrubs. Ecology 66(3):738-742 
Bréda N, Granier A, Aussenac G (1995) Effects of thinning on soil and tree water relations, transpiration and growth in an oak forest (Quercus petraea (Matt.) Liebl.). Tree Physiol 15:295-306

Bréda N, Huc R, Granier A, Dreyer E (2006) Temperate forest trees and stands under severe drought: a review of ecophysiological responses, adaptation processes and long-term consequences. Ann For Sci 63:625-644

Bréda N, Peiffer M (2014) Vulnerability to forest decline in a context of climate changes: new prospects about an old question in forest ecology. Ann For Sci 71:627-631

Brodersen CR, McElrone AJ, Choat B, Matthews MA, Shackel KA (2010) The dynamics of embolism repair in xylem: in vivo visualizations using high-resolution computed tomography. Plant Physiol 154:1088-1095

Brodribb TJ, Cochard H (2009) Hydraulic failure defines the recovery and point of death in water-stressed conifers. Plant Physiol 149:575-584

Bruce TJ, Matthes MC, Napier JA, Pickett JA (2007) Stressful "memories" of plants: evidence and possible mechanisms. Plant Sci 173:603-608

Carnicer J, Brotons L, Stefanescu C, Penuelas J (2012) Biogeography of species richness gradients: linking adaptive traits, demography and diversification. Biol Rev 87:457-479

Chaar H, Colin F (1999) Impact of late frost on height growth in young sessile oak regenerations. Ann For Sci 56:417-429

Chandler PM, Robertson M (1994) Gene expression regulated by abscisic acid and its relation to stress tolerance. Annu Rev Plant Biol 45:113-141

Chapin III FS, Autumn K, Pugnaire F (1993) Evolution of suites of traits in response to environmental stress. American Naturalist, $\mathrm{S} 78-\mathrm{S} 92$

Charra-Vaskou K, Badel E, Charrier G et al (2016) Cavitation and water fluxes driven by ice water potential in Juglans regia during freeze-thaw cycles. J Exp Bot 67:739-750

Charrier G, Bonhomme M, Lacointe A, Améglio T (2011) Are budburst dates, dormancy and cold acclimation in walnut trees (Juglans regia L.) under mainly genotypic or environmental control? Int J Biometeorol 55:763-774

Charrier G, Cochard H, Améglio T (2013a) Evaluation of the impact of frost resistances on potential altitudinal limit of trees. Tree Physiol 33:891-902

Charrier G, Poirier M, Bonhomme M, Lacointe A, Améglio T (2013b) Frost acclimation in different organs of walnut trees Juglans regia L.: how to link physiology and modelling? Tree Physiol 33:1229-1241

Charrier G, Charra-Vaskou K, Kasuga J, Cochard H, Mayr S, Améglio T (2014) Freeze-thaw stress: effects of temperature on hydraulic conductivity and ultrasonic activity in ten woody angiosperms. Plant Physiol 164:992-998

Charrier G, Ngao J, Saudreau M, Améglio T (2015) Effects of environmental factors and management practices on microclimate, winter physiology, and frost resistance in trees. Front Plant Sci 6:259

Charrier G, Torres-Ruiz JM, Badel E et al (2016) Evidence for hydraulic vulnerability segmentation and lack of xylem refilling under tension. Plant Physiol 172:16571668

Charrier G, Nolf M, Leitinger G et al (2017) Monitoring of freezing dynamics in trees: a simple phase shift causes complexity. Plant Physiol 173:2196-2207

Charrier G, Chuine I, Bonhomme M, Améglio T (2018a) Assessing frost damages using dynamic models in walnut trees: exposure rather than vulnerability controls frost risks. Plant Cell Environ 41:1008-1021

Charrier G, Delzon S, Domec JC et al (2018b) Drought will not leave your glass empty: low risk of hydraulic failure revealed by long- term drought observations in world's top wine regions. Sci Adv 4:eaao6969

Charrier G, Lacointe A, Améglio T (2018) Dynamic modeling of carbon metabolism during the dormant period accurately predicts the changes in frost hardiness in walnut trees Juglans regia L. Front Plant Sci 9:1746

Chaves MM, Pereira JS, Maroco J, Rodrigues ML, Ricardo CPP, Osório ML, ..., Pinheiro C (2002) How plants cope with water stress in the field? Photosynthesis and growth. Ann Botany 89: 907-916

Cheaib A, Badeau V, Boe J et al (2012) Climate change impacts on tree ranges: model intercomparison facilitates understanding and quantification of uncertainty. Ecol Lett 15:533-544

Choat B, Jansen S, Brodribb TJ et al (2012) Global convergence in the vulnerability of forests to drought. Nature 491:752-755

Choat B, Brodribb TJ, Brodersen CR, Duursma RA, López R, Medlyn BE (2018) Triggers of tree mortality under drought. Nature 558:531

Christensen-Dalsgaard KK, Tyree MT (2014) Frost fatigue and spring recovery of xylem vessels in three diffuse-porous trees in situ. Plant Cell Environ 37:10741085

Chuine I, Bonhomme M, Legave JM, García de Cortázar-Atauri I, Charrier G, Lacointe A, Améglio T (2016) Can phenological models predict tree phenology accurately in the future? The unrevealed hurdle of endodormancy break. Glob Change Biol 22:3444-3460

Chuste PA, Maillard P, Bréda N, Levillain J, Thirion E, Wortemann R, Massonnet C (2019) Sacrificing growth and maintaining a dynamic carbohydrate storage are key processes for promoting beech survival under prolonged drought conditions. Trees 1-14. https://doi.org/10.1007/s00468-019-01923-5

Cinotti B (1991) Investigation of the intrinsic properties of wood for explaining the occurrence of frost-crack in Quercus petraea Liebl. and Quercus robur L. Ann Sci For 48:453-468

Cochard H, Lemoine D, Améglio T, Granier A (2001) Mechanisms of xylem recovery from winter embolism in Fagus sylvatica. Tree Physiol 21(1):27-33

Cochard H, Cruiziat P, Tyree MT (1992) Use of positive pressures to establish vulnerability curves: further support for the air-seeding hypothesis and implications for pressure-volume analysis. Plant Physiol 100:205-209

Cox RM, Malcolm JW (1997) Effects of duration of a simulated winter thaw on dieback and xylem conductivity of Betula papyrifera. Tree Physiol 17:389-396

Cox RM, Zhu XB (2003) Effects of simulated thaw on xylem cavitation, residual embolism, spring dieback and shoot growth in yellow birch. Tree Physiol 23:615-624

D'Andrea E, Rezaie N, Battistelli A et al (2019) Winter's bite: beech trees survive complete defoliation due to spring late-frost damage by mobilizing old C reserves. New Phytol. https://doi.org/10. 1111/nph.16047

D’Andrea E, Rezaie N, Prislan P, Muhr J, Collalti A, Matteucci G, Gričar J (2020) The cold and the drought: effects of extreme weather events on Stem Carbon dynamic in a Mediterranean beech forest. Plant Cell Environ. https://doi.org/10.1111/pce. 13858

Delpierre N, Soudani K, Francois C et al (2009) Exceptional carbon uptake in European forests during the warm spring of 2007: a data-model analysis. Glob Chang Biol 15:1455-1474

Delpierre N, Vitasse Y, Chuine I, Guillemot J, Bazot S, Rathgeber CB (2016) Temperate and boreal forest tree phenology: from organ-scale processes to terrestrial ecosystem models. Ann For Sci 73:5-25

Dowgert MF, Steponkus PL (1984) Behavior of the plasma membrane of isolated protoplasts during a freeze-thaw cycle. Plant Physiol 75:1139-1151 
Dufrêne E, Davi H, François C, Le Maire G, Le Dantec V, Granier A (2005) Modelling carbon and water cycles in a beech forest: part i: model description and uncertainty analysis on modelled NEE. Ecol Model 185:407-436

Earles JM, Stevens JT, Sperling O, Orozco J, North MP, Zwieniecki MA (2018) Extreme mid-winter drought weakens tree hydrauliccarbohydrate systems and slows growth. New Phytol 219:89-97

Edwards WRN, Jarvis PG (1982) Relations between water content, potential and permeability in stems of conifers. Plant, Cell Environ 5:271-277

Eilmann B, Zweifel R, Buchmann N et al (2011) Drought alters timing, quantity, and quality of wood formation in Scots pine. J Exp Bot 62(8):2763-2771

Erwin DH (2009) Climate as a driver of evolutionary change. Curr Biol 19:R575-R583

Ewers FW, Améglio T, Cochard H et al (2001) Seasonal variation in xylem pressure of walnut trees: root and stem pressures. Tree Physiol 21:1123-1132

Feichtinger LM, Eilmann B, Buchmann N et al (2015) Trait-specific responses of Scots pine to irrigation on a short vs long time scale. Tree Physiol 35(2):160-171

Francon L, Corona C, Till-Bottraud I, Choler P, Carlson BZ, Charrier G, ..., Lopez-Saez J (2020) Assessing the effects of earlier snow melt-out on alpine shrub growth: the sooner the better? Ecol Ind 115: 106455

Fu YS, Campioli M, Vitasse Y et al (2014) Variation in leaf flushing date influences autumnal senescence and next year's flushing date in two temperate tree species. Proc Natl Acad Sci 111:7355-7360

Fuchigami LH, Weiser CJ, Kobayashi K, Timmis R, Gusta LV (1982) A degree growth stage (GS) model and cold acclimation in temperate woody plants. Plant cold hardiness and freezing stress. Mech Crop Implications 2:93-116

Galvez DA, Landhäusser SM, Tyree MT (2013) Low root reserve accumulation during drought may lead to winter mortality in poplar seedlings. New Phytol 198:139-148

Ghesquière M, Barre P, Durand JL, Litrico I, Sampoux JP, Mournet P, Volaire F (2014. Genetic response to climate scenarios in Dactylis and Festuca of temperate versus Mediterranean origin. In Quantitative Traits Breeding for Multifunctional Grasslands and Turf (pp. 41-48). Springer, Dordrecht

Gleason SM, Wiggans DR, Bliss CA, Young JS, Cooper M, Willi KR, Comas LH (2017) Embolized stems recover overnight in Zea mays: the role of soil water, root pressure, and nighttime transpiration. Front Plant Sci 8:662

Granda E, Camarero JJ (2017) Drought reduces growth and stimulates sugar accumulation: new evidence of environmentally driven non-structural carbohydrate use. Tree Physiol 37:997-1000

Guisan A, Thuiller W (2005) Predicting species distribution: offering more than simple habitat models. Ecol Lett 8:993-1009

Gusta LV, Tyler NJ, Chen THH (1983) Deep undercooling in woody taxa growing north of the $40^{\circ} \mathrm{C}$ isotherm. Plant Physiol 72:122-128

Hacke U, Sauter JJ (1996) Xylem dysfunction during winter and recovery of hydraulic conductivity in diffuse-porous and ring-porous trees. Oecologia 105:435-439

Hampe A, Petit RJ (2005) Conserving biodiversity under climate change: the rear edge matters. Ecol Lett 8:461-467

Hänninen H, Tanino K (2011) Tree seasonality in a warming climate. Trends Plant Sci 16:412-416

Hänninen H (1991) Does climatic warming increase the risk of frost damage in northern trees? Plant Cell Environ 14:449-454

Hansen J, Beck E (1988) Evidence for ideal and non-ideal equilibrium freezing of leaf water in frosthardy ivy (Hedera helix) and winter barley (Hordeum vulgare). Botanica Acta 101:76-82

Hartmann H, Trumbore S (2016) Understanding the roles of nonstructural carbohydrates in forest trees-from what we can measure to what we want to know. New Phytol 211:386-403
Hartmann H, Ziegler W, Kolle O, Trumbore S (2013) Thirst beats hunger-declining hydration during drought prevents carbon starvation in Norway spruce saplings. New Phytol 200:340-349

Heide OM (2003) High autumn temperature delays spring bud burst in boreal trees, counterbalancing the effect of climatic warming. Tree Physiol 23:931-936

Hoch G, Popp M, Körner C (2002) Altitudinal increase of mobile carbon pools in Pinus cembra suggests sink limitation of growth at the Swiss treeline. Oikos 98:361374

Hossain M, Veneklaas EJ, Hardy GESJ, Poot P (2019) Tree hostpathogen interactions as influenced by drought timing: linking physiological performance, biochemical defence and disease severity. Tree Physiol 39:6-18

Intergovernmental Panel on Climate Change. (2012). Managing the risks of extreme events and disasters to advance climate change adaptation. A Special Report of Working Groups I and II of the Intergovernmental Panel on Climate Change [Field CB, Barros V, Stocker TF, Qin D, Dokken DJ, Ebi KL, Mastrandrea MD, Mach KJ, Plattner GK, Allen SK, Tignor M, Midgley PM (eds.)]. Cambridge University Press, Cambridge, UK, and New York, NY, USA, $582 \mathrm{pp}$

IPCC (2014) Climate change 2014: Impacts, adaptation, and vulnerability. Part B: regional aspects. In Barros VR, Field CB, Dokken DJ, Mastrandrea MD, Mach KJ, Bilir TE, Chatterjee M, Ebi KL, Estrada YO, Genova RC, Girma B, Kissel ES, Levy AN, MacCracken S, PR, Mastrandrea and White LL (eds.) Contribution of working group II to the fifth assessment report of the intergovernmental panel on climate change. Cambridge University Press, Cambridge, United Kingdom and New York, NY, pp 688

Kalcsits LA, Silim S, Tanino K (2009) Warm temperature accelerates short photoperiod-induced growth cessation and dormancy induction in hybrid poplar (Populus $\times$ spp.). Trees 23:971-979

Kasuga J, Charrier G, Uemura M, Améglio T (2015) Characteristics of ultrasonic acoustic emissions from walnut branches during freeze-thaw-induced embolism formation. J Exp Bot 66:1965-1975

Keenan TF, Richardson AD (2015) The timing of autumn senescence is affected by the timing of spring phenology: implications for predictive models. Glob Change Biol 21:2634-2641

Kellomäki S, Väisänen H, Hänninen H, Kolström T, Lauhanen R, Mattila U, Pajari B (1992) A simulation model for the succession of the boreal forest ecosystem. Silva Fennica 26:1-18

Kellomäki S, Hanninen H, Kolstrom M (1995) Computations on frost damage to Scots pine under climatic warming in boreal conditions. Ecol Appl 5:42-52

Klanderud K, Vandvik V, Goldberg D (2015) The importance of biotic vs. abiotic drivers of local plant community composition along regional bioclimatic gradients. PloS One 10:e130205

Knapp AK, Fay PA, Blair JM et al (2002) Rainfall variability, carbon cycling, and plant species diversity in a mesic grassland. Science 298:2202-2205

Koerner C (2015) Paradigm shift in plant growth control. Curr Opin Plant Biol 25:107-114

Koerner C, Basler D, Hoch G et al (2016) Where, why and how? Explaining the low-temperature range limits of temperate tree species. J Ecol 104:10761088

Koerner C (1998) A re-assessment of high elevation treeline positions and their explanation. Oecologia 115:445-459

Kreyling J, Buhk C, Backhaus S et al (2014) Local adaptations to frost in marginal and central populations of the dominant forest tree Fagus sylvatica L. as affected by temperature and extreme drought in common garden experiments. Ecol Evol 4:594-605

Kreyling J, Wiesenberg GL, Thiel D et al (2012) Cold hardiness of Pinus nigra Arnold as influenced by geographic origin, warming, and extreme summer drought. Environ Exp Bot 78:99-108 
Kubler H (1983) Mechanism of frost crack formation in trees-a review and synthesis. For Sci 29:559-568

Lang GA, Early JD, Martin GC, Darnell RL (1987) Endo-, para- and ecodormancy: physiological terminology and classification for dormancy research. Hortscience 22:371-377

Lamarque LJ, Corso D, Torres-Ruiz JM, Badel E, Brodribb TJ, Burlett $\mathrm{R}$, ..., Delzon S (2018) An inconvenient truth about xylem resistance to embolism in the model species for refilling Laurus nobilis L. Ann For Sci 75: 88

Larcher W (2005) Climatic constraints drive the evolution of low temperature resistance in woody plants. J Agric Meteorol 61:189-202

Laube J, Sparks TH, Estrella N, Höfler J, Ankerst DP, Menzel A (2014) Chilling outweighs photoperiod in preventing precocious spring development. Glob Chang Biol 20:170-182

Leinonen I (1996) A simulation model for the annual frost hardiness and freeze damage of Scots pine. Ann Bot 78:687-693

Leinonen I, Hänninen H (2002) Adaptation of the timing of bud burst of Norway spruce to temperate and boreal climates. Silva Fenn 36:695-701

Lemoine D, Granier A, Cochard H (1999) Mechanism of freezeinduced embolism in Fagus sylvatica L. Trees 13:206-210

Lenoir J, Gégout JC, Marquet PA, De Ruffray P, Brisse H (2008) A significant upward shift in plant species optimum elevation during the 20th century. Science 320:1768-1771

Lens F, Sperry JS, Christman MA, Choat B, Rabaey D, Jansen S (2011) Testing hypotheses that link wood anatomy to cavitation resistance and hydraulic conductivity in the genus Acer. New Phytol 190:709-723

Levitt J (1980) Responses of plants to environmental stress, volume 1: chilling, freezing, and high temperature stresses. Academic Press, New York, NY

Li S, Lens F, Espino S et al (2016) Intervessel pit membrane thickness as a key determinant of embolism resistance in angiosperm xylem. IAWA J 37:152-171

Lines ER, Coomes DA, Purves DW (2010) Influences of forest structure, climate and species composition on tree mortality across the eastern US. (ed Hector A). PloS One 5:e13212

Lintunen A, Mayr S, Salmon Y, Cochard H, Hölttä T (2018) Drivers of apoplastic freezing in gymnosperm and angiosperm branches. Ecol Evol 8:333-343

Liu G, Chen X, Fu Y, Delpierre N (2019) Modelling leaf coloration dates over temperate China by considering effects of leafy season climate. Ecol Model 394:34-43

Loehle C (1998) Height growth rate tradeoffs determine northern and southern range limits for trees. J Biogeogr 25:735-742

Lovisolo C, Schubert A (1998) Effects of water stress on vessel size and xylem hydraulic conductivity in Vitis vinifera L. J Exp Bot 49:693-700

Marchin R, Zeng H, Hoffmann W (2010) Drought-deciduous behavior reduces nutrient losses from temperate deciduous trees under severe drought. Oecologia 163:845-854

Martinez-Medina A, Flors V, Heil M, Mauch-Mani B, Pieterse CM, Pozo MJ, ..., Conrath U (2016) Recognizing plant defense priming. Trends Plant Sci 21: 818-822

Martinez-Vilalta J, Anderegg WR, Sapes G, Sala A (2019) Greater focus on water pools may improve our ability to understand and anticipate drought-induced mortality in plants. New Phytol 223:22-32

Martin-StPaul N, Delzon S, Cochard H (2017) Plant resistance to drought depends on timely stomatal closure. Ecol Lett 20:1437-1447

Maurya JP, Bhalerao RP (2017) Photoperiod-and temperature-mediated control of growth cessation and dormancy in trees: a molecular perspective. Ann Bot 120(3):351-360
Mayr S, Charra-Vaskou K (2007) Winter at the alpine timberline causes complex within-tree patterns of water potential and embolism in Picea abies. Physiol Plant 131:131-139

Mayr S, Gruber A, Bauer H (2003) Repeated freeze-thaw cycles induce embolism in drought stressed conifers (Norway spruce, stone pine). Planta 217:436-441

Mayr S, Hacke U, Schmid P, Schwienbacher F, Gruber A (2006) Frost drought in conifers at the alpine timberline: xylem dysfunction and adaptations. Ecology 87:31753185

Mayr S, Cochard H, Améglio T, Kikuta SB (2007) Embolism formation during freezing in the wood of Picea abies. Plant Physiol 143:60-67

Mayr S, Schmid P, Laur J, Rosner S, Charra-Vaskou K, Dämon B, Hacke UG (2014) Uptake of water via branches helps timberline conifers refill embolized xylem in late winter. Plant Physiol 164:1731-1740

Mayr S, Schmid P, Beikircher B, Feng F, Badel E (2019) Die hard: timberline conifers survive annual winter embolism. New Phytol. https://doi.org/10.1111/nph.16304

McDowell N, Pockman WT, Allen CD et al (2008) Mechanisms of plant survival and mortality during drought: why do some plants survive while others succumb to drought? New Phytol 178:719-739

McDowell NG (2011) Mechanisms linking drought, hydraulics, carbon metabolism, and vegetation mortality. Plant Physiol 155:1051-1059

Menzel A, Helm R, Zang C (2015) Patterns of late spring frost leaf damage and recovery in a European beech (Fagus sylvatica L.) stand in south-eastern Germany based on repeated digital photographs. Front Plant Sci 6. https://doi.org/10.3389/fpls.2015. 00110

Menzel A, Sparks TH, Estrella N et al (2006) European phenological response to climate change matches the warming pattern. Glob Chang Biol 12:1969-1976

Miao S, Zou CB, Breshears DD (2009) Vegetation responses to extreme hydrological events: sequence matters. Am Nat 173:113-118

Misson L, Degueldre D, Collin C, Rodriguez R, Rocheteau A, Ourcival JM, Rambal S (2011) Phenological responses to extreme droughts in a Mediterranean forest. Glob Chang Biol 17:1036-1048

Morin X, Améglio T, Ahas R et al (2007) Variation in cold hardiness and carbohydrate concentration from dormancy induction to bud burst among provenances of three European oak species. Tree Physiol 27:817-825

Morin X, Chuine I (2005) Sensitivity analysis of the tree distribution model PHENOFIT to climatic input characteristics: implications for climate impact assessment. Glob Chang Biol 11:1493-1503

Nardini A, Gullo MAL, Salleo S (2011) Refilling embolized xylem conduits: is it a matter of phloem unloading? Plant Sci 180:604-611

O’Brien MJ, Leuzinger S, Philipson CD, Tay J, Hector A (2014) Drought survival of tropical tree seedlings enhanced by nonstructural carbohydrate levels. Nat Clim Chang 4:710-714

Palonen P, Buszard D (1997) Current state of cold hardiness research on fruit crops. Can J Plant Sci 77:399-420

Parmesan C, Yohe G (2003) A globally coherent fingerprint of climate change impacts across natural systems. Nature 421:37-42

Poirier M, Lacointe A, Améglio T (2010) A semi-physiological model of cold hardening and dehardening in walnut stem. Tree Physiol 30:1555-1569

Porporato A, Daly E, Rodriguez-Iturbe I (2004) Soil water balance and ecosystem response to climate change. Am Nat 164:625-632

Priestley JH (1920) The mechanism of root pressure. New Phytol 19:189-200 
Rinne P, Hänninen H, Kaikuranta P, Jalonen JE, Repo T (1997) Freezing exposure releases bud dormancy in Betula pubescens and $B$. pendula. Plant Cell Environ 20:1199-1204

Rinne PL, Kaikuranta PM, Van Der Schoot C (2001) The shoot apical meristem restores its symplasmic organization during chillinginduced release from dormancy. Plant J 26:249-264

Rohde A, Bastien C, Boerjan W (2011) Temperature signals contribute to the timing of photoperiodic growth cessation and bud set in poplar. Tree Physiol 31:472-482

Ruiz-Benito P, Lines ER, Gómez-Aparicio L, Zavala MA, Coomes, DA (2013) Patterns and drivers of tree mortality in Iberian forests: climatic effects are modified by competition. PloS One. https:// doi.org/10.1371/journal.pone.0056843

Rummukainen M (2012) Changes in climate and weather extremes in the 21st century. Wiley Interdiscip Rev Clim Chang 3:115-129

Sala A, Woodruff DR, Meinzer FC (2012) Carbon dynamics in trees: feast or famine? Tree Physiol 32:764-775

Savvides A, Ali S, Tester M, Fotopoulos V (2016) Chemical priming of plants against multiple abiotic stresses: mission possible? Trends Plant Sci 21:329-340

Schaber J, Badeck FW (2005) Plant phenology in Germany over the 20th century. Reg Environ Chang 5:37-46

Schuldt B, Buras A, Arend M, Vitasse V, Beierkuhnlein C, Damm A, Gharun M, Grams TEE, Hauck M, Hajek P, Hartmann H, Hiltbrunner E, Hoch G, Holloway-Phillips M, Körner C, Larysch E, Lübbe T, Nelson DB, Rammig A, Rigling A, Rose L, Ruehr NK, Schumann K, Weiser F, Werner C, Wohlgemuth T, Zang CS, Kahmen A (2020) A first assessment of the impact of the extreme 2018 summer drought on Central European forests. Basic Appl Ecol 45:86-103

Schuster C, Kirchner M, Jakobi G, Menzel A (2014) Frequency of inversions affects senescence phenology of Acer pseudoplatanus and Fagus sylvatica. Int J Biometeorol 58:485-498

Seneviratne SI, Nicholls N, Easterling D, Goodess CM, Kanae S, Kossin J, Luo Y, Marengo J, McInnes K, Rahimi M, Reichstein M, Sorteberg A, Vera C, Zhang X (2012) Changes in climate extremes and their impacts on the naturalphysical environment. In: Managing the risks of extreme events and disasters to advance climate change adaptation [Field CB, Barros V, Stocker TF, Qin D, Dokken DJ, Ebi KL, Mastrandrea MD, Mach KJ, Plattner G-K, Allen SK, Tignor M, Midgley PM (eds.)]. A Special Report of Working Groups I and II of the Intergovernmental Panel on ClimateChange (IPCC). Cambridge University Press, Cambridge, pp. 109-230

Shi P, Koerner C, Hoch G (2008) A test of the growth-limitation theory for alpine tree line formation in evergreen and deciduous taxa of the eastern Himalayas. Funct Ecol 22:213-220

Sierra-Almeida A, Reyes-Bahamonde C, Cavieres LA (2016) Drought increases the freezing resistance of high-elevation plants of the Central Chilean Andes. Oecologia 113. https:// doi.org/10.1007/s00442-016-3622-5

Siminovitch D, Cloutier Y (1983) Drought and freezing tolerance and adaptation in plants: some evidence of near equivalences. Cryobiology 20:487-503

Sperry JS, Sullivan JE (1992) Xylem embolism in response to freezethaw cycles and water stress in ring-porous, diffuse-porous, and conifer species. Plant Physiol 100:605-613

Sperry JS, Holbrook NM, Zimmermann MH, Tyree MT (1987) Spring filling of xylem vessels in wild grapevine. Plant Physiol 83:414-417

Sperry JS, Nichols KL, Sullivan JE, Eastlack SE (1994) Xylem embolism in ring-porous, diffuse-porous, and coniferous trees of northern Utah and interior Alaska. Ecology 75:1736-1752

Sperry JS, Adler FR, Campbell GS, Comstock JP (1998) Limitation of plant water use by rhizosphere and xylem conductance: results from a model. Plant Cell Environ 21:347-359
Stockinger EJ, Gilmour SJ, Thomashow MF (1997) Arabidopsis thaliana CBF1 encodes an AP2 domain-containing transcriptional activator that binds to the Crepeat/DRE, a cis-acting DNA regulatory element that stimulates transcription in response to low temperature and water deficit. Proc Natl Acad Sci 94:1035-1040

Tanino KK, Kalcsits L, Silim S, Kendall E, Gray GR (2010) Temperature-driven plasticity in growth cessation and dormancy development in deciduous woody plants: a working hypothesis suggesting how molecular and cellular function is affected by temperature during dormancy induction. Plant Mol Biol 73:49-65

Timmis R, Tanaka Y (1976) Effects of container density and plant water stress on growth and cold hardiness of Douglas-fir seedlings. For Sci 22:167-172

Tomasella M, Nardini A, Hesse BD, Machlet A, Matyssek R, Häberle $\mathrm{KH}$ (2019) Close to the edge: effects of repeated severe drought on stem hydraulics and nonstructural carbohydrates in European beech saplings. Tree Physiol 39:717-728

Tranquillini W (1979) Physiological ecology of the alpine timberline. Ecological Studies 31, Springer Verlag Berlin, Heidelberg, New York

Tylewicz S, Petterle A, Marttila S et al (2018) Photoperiodic control of seasonal growth is mediated by ABA acting on cell-cell communication. Science eaan8576. https://doi.org/10.1126/science. aan8576

Tyree MT, Cochard H, Cruiziat P, Sinclair B, Ameglio T (1993) Drought-induced leaf shedding in walnut: evidence for vulnerability segmentation. Plant Cell Environ 16:879-882

Tyree MT, Sperry JS (1989) Vulnerability of xylem to cavitation and embolism. Annu Rev Plant Biol 40:19-36

Ummenhofer CC, Meehl GA (2017) Extreme weather and climate events with ecological relevance: a review. Philos Trans R Soc B Biol Sci 372:20160135

Van Peer L, Nijs I, Reheul D, De Cauwer B (2004) Species richness and susceptibility to heat and drought extremes in synthesized grassland ecosystems: compositional vs physiological effects. Funct Ecol 18:769-778

Vanoni M, Bugmann H, Nötzli M, Bigler C (2016) Drought and frost contribute to abrupt growth decreases before tree mortality in nine temperate tree species. For Ecol Manag 382:51-63

Vitasse Y, Porté AJ, Kremer A, Michalet R, Delzon S (2009) Responses of canopy duration to temperature changes in four temperate tree species: relative contributions of spring and autumn leaf phenology. Oecologia 161:187-198

Walter J, Jentsch A, Beierkuhnlein C, Kreyling J (2013) Ecological stress memory and cross stress tolerance in plants in the face of climate extremes. Environ Exp Bot 94:3-8

Wargo PM (1981) Defoliation, dieback and mortality. The gypsy moth: research toward integrated pest management. Edited by CC Doane and ML McManus. US Dep Agric Tech Bull 1584:240-248

Wargo PM (1996) Consequences of environmental stress on oak: predisposition to pathogens. Ann Sci For 53:359-368

Welling A, Moritz T, Palva ET, Junttila O (2002) Independent activation of cold acclimation by low temperature and short photoperiod in hybrid aspen. Plant Physiol 129:1633-1641

Wolf S, Keenan TF, Fisher JB, Baldocchi DD, Desai AR, Richardson AD, ..., Peters W (2016) Warm spring reduced carbon cycle impact of the 2012 US summer drought. Proceedings of the National Academy of Sciences, 201519620

Wong BL, Baggett KL, Rye AH (2009) Cold-season patterns of reserve and soluble carbohydrates in sugar maple and ice-damaged trees of two age classes following drought. Botany 87:293-305 
Xie Y, Wang X, Silander JA (2015) Deciduous forest responses to temperature, precipitation, and drought imply complex climate change impacts. Proc Natl Acad Sci 112:13585-13590

Yamaguchi-Shinozaki K, Shinozaki K (1994) A novel cis-acting element in an Arabidopsis gene is involved in responsiveness to drought, low-temperature, or high-salt stress. Plant Cell 6:251-264

Yonker CM, Kaplan NE, Kelly EF (2007) LTER: long term ecological research network (Doctoral dissertation, Colorado State University. Libraries)

Zhu XB, Cox RM, Arp PA (2000) Effects of xylem cavitation and freezing injury on dieback of yellow birch (Betula alleghaniensis) in relation to a simulated winter thaw. Tree Physiol 20:541-547

Zweifel R, Zimmermann L, Newbery DM (2005) Modeling tree water deficit from microclimate: an approach to quantifying drought stress. Tree Physiol 25:147-156
Zweifel R, Etzold S, Sterck F et al (2020) Determinants of legacy effects in pine trees-implications from an irrigation-stop experiment. New Phytol 227(4):1081-1096

Zweifel R, Sterck F (2018) A conceptual tree model explaining legacy effects on stem growth. Front For Glob Chang 1: 9 (9 pp.)

Zwieniecki MA, Holbrook NM (2009) Confronting Maxwell's demon: biophysics of xylem embolism repair. Trends Plant Sci 14:530-534

Publisher's note Springer Nature remains neutral with regard to jurisdictional claims in published maps and institutional affiliations.

\section{Authors and Affiliations}

\section{Guillaume Charrier ${ }^{1}$ (D) Nicolas Martin-StPaul ${ }^{2} \cdot$ Claire Damesin $^{3} \cdot$ Nicolas Delpierre $^{3} \cdot$ Heikki Hänninen $^{4}$. Jose M. Torres-Ruiz ${ }^{1} \cdot$ Hendrik Davi $^{2}$}

\author{
Nicolas Martin-StPaul \\ nicolas.martin@inrae.fr \\ Claire Damesin \\ claire.damesin@u-psud.fr \\ Nicolas Delpierre \\ nicolas.delpierre@u-psud.fr \\ Heikki Hänninen \\ hhannin@zafu.edu.cn \\ Jose M. Torres-Ruiz \\ Jose.Torres-Ruiz@inrae.fr \\ Hendrik Davi \\ hendrik.davi@inrae.fr
}

1 INRAE, PIAF, Université Clermont Auvergne, 63000, Clermont-Ferrand, France

2 INRAE, URFM, Domaine Saint Paul, INRAE Centre de Recherche PACA, 228 route de l'Aérodrome, CS 40509 Domaine Saint-Paul, Site Agroparc, France

3 Ecologie Systématique Evolution, Univ. Paris-Sud, CNRS, AgroParisTech, Université Paris-Saclay, Orsay, France

4 State Key Laboratory of Subtropical Silviculture, Zhejiang Agriculture \& Forestry University, Hangzhou, 311300, China 